\title{
Periodontal Health Status and Pregnancy Outcomes: A Survey in Medical Doctors
}

\author{
Sujaya Gupta, ${ }^{1}$ Barsha Shrestha, ${ }^{2}$ Neha Gupta, ${ }^{3}$ Anik Tuladhar, ${ }^{4}$ Sushil KC, ${ }^{5}$ Bhageshwar Dhami ${ }^{1}$ \\ 'Department of Periodontics, Kantipur Dental College, Basundhara, Kathmandu, Nepal, ${ }^{2}$ Barah Dental Clinic, Dharan, Nepal, \\ ${ }^{3}$ Department of Dental Surgery, Nobel Medical College, Biratnagar, Nepal, ${ }^{4}$ School of Oral Health, Kathmandu Model \\ Hospital, Kathmandu, Nepal, ${ }^{5}$ Department of Dental Surgery, Shree Birendra Army Hospital, Chhauni, Kathmandu, Nepal.
}

\section{ABSTRACT}

Introduction: Periodontal disease and caries are the most common causes of tooth loss worldwide. Studies have demonstrated strong association between periodontitis and adverse pregnancy outcomes. Medical doctors, who are the primary healthcare providers, seldom advise women to seek dental care during pregnancy. This study was undertaken to explore the knowledge, attitudes and behaviours of medical doctors towards oral health and to identify the barriers of prenatal periodontal healthcare in their practices and its possible implications on pregnancy outcomes.

Methods: Total 377 doctors filled the questionnaire. The data collected through personal contacts, social networking, emails, online forms and networking at conferences were analysed using Statistical Package for the Social Sciences 20 software program and presented in tables, charts and diagrams.

Results: Out of 263 (69.8\%) male and 114 (30.2\%) female doctors enrolled in the study, only 52 (13.8\%) had received education or training on oral care during pregnancy. Among them 299 (79.3\%) agreed that there is possible link between health of teeth-gums and pregnancy. Approximately 105 (27.9\%) encountered patients with oral/periodontal problem every week but only $108(28.6 \%)$ "always" advised their patient for regular dental check-ups. Similarly, $358(95 \%)$ agreed that there is need for universal guidelines. However, $133(35.3 \%)$ thought there was insufficient time to advise patients on oral health during check-ups.

Conclusions: There is need for training on 'oral healthcare during pregnancy' for medical doctors. Developing universal guidelines for oral healthcare in pregnant women for all health professionals would be another important step. An adequate referral system to oral healthcare providers and biannual check-ups is recommended for both general patient as well as pregnant women for preventing adverse situations related to oral and specifically periodontal diseases.

Keywords: low birth weight; Nepal; oral health; periodontal medicine; pregnancy outcomes.

\section{INTRODUCTION}

Periodontitis is an infection with multi-factorial characteristics. ${ }^{1}$ Low birth weight (LBW) and preterm delivery (PTD) are major health problems associated with high morbidity and mortality. ${ }^{2}$ Studies in various populations have demonstrated strong association between periodontal diseases and adverse pregnancy outcomes such as preterm low birth weight (PTLBW). ${ }^{3-5}$

Potential mechanism of periodontal disease in mother

Correspondence: Dr. Sujaya Gupta, Department of Periodontics, Kantipur Dental College, Basundhara, Kathmandu, Nepal. Email: sujayaagupta@gmail.com, Phone: +977-9803588959. 
to be associated with the occurrence of PTD, LBW and PTLBW ${ }^{1,3,4}$ suggested is that periodontal infections serve as chronic reservoir of microorganisms that cause production of interleukins and prostaglandins which in turn induce preterm parturition. ${ }^{2}$ Medical doctors are the ones who often deal with antenatal care (ANC). However, very few studies exist regarding their oral health awareness ${ }^{6-9}$ and none could be found in context to Nepal.

This study was conducted to assess the knowledge and practices of medical doctors towards oral health care during pregnancy, thereby increasing their awareness of possible systemic implications of periodontal diseases. Consequently, helping decrease chances of PTLBW due to oral and periodontal conditions.

\section{METHODS}

This is a cross-sectional survey that was carried out for five months duration from August to December 2017. among medical doctors (medical officers, residents and specialists) registered at Nepal Medical Council (NMC) and practicing in various parts of Nepal.

Before embarking upon the study, ethical approval was taken. The privacy of the volunteers were fully maintained and informed consent was taken after explaining all the relevant details, its importance and implications. Those who did not give consent for any reason were excluded from the study. Confidentiality was maintained to the utmost. No names, documents or results are disclosed or circulated anywhere other than among the researchers. The names of the participants do not appear in the final report.

The inclusion criteria included all the male and female doctors holding an MBBS (Bachelor of Medicine and Bachelor of Surgery) degree, registered with NMC and willing to sign an informed consent whereas the exclusion criteria were MBBS degree holders not registered at NMC or unwilling to sign an informed consent.

Convenience (non-probability) sampling technique was utilised and the sample size of 376 was calculated by utilizing following formula on the total database of medical doctors provided by NMC as of 2016 December:

$\begin{aligned} \text { Sample Size } & =\frac{\frac{Z^{2} \times p(1-p)}{e^{2}}}{1+\frac{Z^{2} \times p(1-p)}{e^{2} N}} \\ & =375.88\end{aligned}$

Where Population size $(N)=17449$; Confidence level $(\%)=95 ; P=0.5$ with Margin of error $(e)=0.05$.

The questionnaire survey addressed the domains of knowledge, attitude, barriers and practices of oral healthcare, periodontal impact on pregnancy outcomes along with the demographics. Both open and closeended questions were asked. Most survey items were derived and modified from existing studies exploring the knowledge of medical doctors regarding oral health and awareness about possible implications during pregnancy. ${ }^{7,9-11}$ The proforma was reviewed by experts to establish content validity and then tested twice in a group of medical doctors practicing in the Kathmandu city (initially in 25 doctors, then 34). Survey content, clarity and length were modified and improved in response to the reviews. Participants were recruited through personal contacts, social networkings, via emails, online forms and networking at conferences. The findings were filled in the proforma developed for this study and data were entered in Microsoft Excel. The statistical analyses were performed using Statistical Package for Social Sciences (SPSS) software program for Windows version 20.0. Armonk, NY: IBM Corp. SPSS Statistics. Qualitative data are presented as frequencies and percentages and quantitative data as means and standard deviations. The level of significance was set at 0.05 .

\section{RESULTS}

The total number of doctors who participated in the study was 377 out of which 263 (69.8\%) were males and $114(30.2 \%)$ females.

\begin{tabular}{|llll|}
\hline \multicolumn{2}{|c|}{ Table 1. Responses of the medical doctors. } \\
\hline \multicolumn{1}{|c|}{ Questions } & Yesponses & \multicolumn{1}{c|}{ No } \\
Have you received & & & - \\
$\begin{array}{l}\text { any education/ } \\
\text { training on "Oral } \\
\text { Health Care"? }\end{array}$ & 167 & 210 & \\
(44.3) & & $(55.7)$ & - \\
\end{tabular}




\begin{tabular}{|c|c|c|c|}
\hline $\begin{array}{l}\text { Have you received } \\
\text { any education/ } \\
\text { training on "Oral Care }\end{array}$ & $\begin{array}{l}52 \\
(13.8)\end{array}$ & $\begin{array}{l}325 \\
(86.2)\end{array}$ & - \\
\hline & Yes & No & $\begin{array}{l}\text { Don't } \\
\text { Know }\end{array}$ \\
\hline $\begin{array}{l}\text { There is possible } \\
\text { connection between } \\
\text { health of teeth and } \\
\text { gums and pregnancy? }\end{array}$ & $\begin{array}{l}299 \\
(79.3)\end{array}$ & $4(1.1)$ & $\begin{array}{l}74 \\
(19.6)\end{array}$ \\
\hline $\begin{array}{l}\text { Pregnancy increases } \\
\text { the tendency for the } \\
\text { gums to bleed, swell } \\
\text { or be red }\end{array}$ & $\begin{array}{l}288 \\
(76.4)\end{array}$ & $14(3.7)$ & $\begin{array}{l}75 \\
(19.9)\end{array}$ \\
\hline $\begin{array}{l}\text { Gingivitis is more } \\
\text { serious than } \\
\text { periodontitis }\end{array}$ & $\begin{array}{l}77 \\
(20.4)\end{array}$ & $\begin{array}{l}156 \\
(41.4)\end{array}$ & $\begin{array}{l}144 \\
(38.2)\end{array}$ \\
\hline $\begin{array}{l}\text { Tooth and gum } \\
\text { problems can affect } \\
\text { the outcomes of } \\
\text { pregnancy }\end{array}$ & $\begin{array}{l}224 \\
(59.4)\end{array}$ & $55(14.6)$ & $\begin{array}{l}98 \\
(26)\end{array}$ \\
\hline $\begin{array}{l}\text { Calcium is drawn } \\
\text { out of teeth for the } \\
\text { developing baby }\end{array}$ & $\begin{array}{l}62 \\
(16.4)\end{array}$ & $\begin{array}{l}159 \\
(42.2)\end{array}$ & $\begin{array}{l}156 \\
(41.4)\end{array}$ \\
\hline $\begin{array}{l}\text { Periodontal disease } \\
\text { can be treated safely } \\
\text { during pregnancy } \\
\text { with a procedure } \\
\text { called scaling and } \\
\text { root planing }\end{array}$ & $\begin{array}{l}193 \\
(51.2)\end{array}$ & $26(6.9)$ & $\begin{array}{l}158 \\
(41.9)\end{array}$ \\
\hline $\begin{array}{l}\text { Pregnancy } \\
\text { exacerbates existing } \\
\text { oral/dental problems }\end{array}$ & $\begin{array}{l}219 \\
(58.1)\end{array}$ & $37(9.8)$ & $\begin{array}{l}121 \\
(32.1)\end{array}$ \\
\hline $\begin{array}{l}\text { Periodontal disease } \\
\text { has been associated } \\
\text { with: }\end{array}$ & & & \\
\hline - Stillbirth & $\begin{array}{l}63 \\
(16.7)\end{array}$ & $92(24.4)$ & $\begin{array}{l}222 \\
(58.9)\end{array}$ \\
\hline Preterm delivery & $\begin{array}{l}142 \\
(37.7)\end{array}$ & $61(16.2)$ & $\begin{array}{l}174 \\
(46.2)\end{array}$ \\
\hline - Preeclampsia & $\begin{array}{l}44 \\
(11.7)\end{array}$ & $\begin{array}{l}118 \\
(31.3)\end{array}$ & $\begin{array}{l}215 \\
(57.0)\end{array}$ \\
\hline - Low-birth weight & $\begin{array}{l}157 \\
(41.6)\end{array}$ & $48(12.7)$ & $\begin{array}{l}172 \\
(45.6)\end{array}$ \\
\hline $\begin{array}{l}\text { Basic dental } \\
\text { treatment is safe } \\
\text { during pregnancy }\end{array}$ & $\begin{array}{l}331 \\
(87.8)\end{array}$ & $16(4.2)$ & $\begin{array}{l}30 \\
(8.0)\end{array}$ \\
\hline $\begin{array}{l}\text { It is unsafe to obtain } \\
\text { dental radiographs in } \\
\text { pregnant women }\end{array}$ & $\begin{array}{l}183 \\
(48.5)\end{array}$ & $\begin{array}{l}132 \\
(35.0)\end{array}$ & $\begin{array}{l}62 \\
(16.4)\end{array}$ \\
\hline $\begin{array}{l}\text { Pyogenic granuloma } \\
\text { and pregnancy } \\
\text { tumour are same }\end{array}$ & $\begin{array}{l}63 \\
(16.7)\end{array}$ & $\begin{array}{l}130 \\
(34.5)\end{array}$ & $\begin{array}{l}184 \\
(48.8)\end{array}$ \\
\hline
\end{tabular}

\begin{tabular}{|c|c|c|c|}
\hline $\begin{array}{l}\text { Elective dental } \\
\text { treatment should be } \\
\text { delayed until after }\end{array}$ & $\begin{array}{l}135 \\
(35.8)\end{array}$ & $\begin{array}{l}140 \\
(37.1)\end{array}$ & $\begin{array}{l}102 \\
(27.1)\end{array}$ \\
\hline & Agree & Disagree & - \\
\hline $\begin{array}{l}\text { There is insufficient } \\
\text { time to advise } \\
\text { patients/ pregnant } \\
\text { women on oral health } \\
\text { during check-ups }\end{array}$ & $\begin{array}{l}133 \\
(35.3)\end{array}$ & $\begin{array}{l}244 \\
(64.7)\end{array}$ & - \\
\hline $\begin{array}{l}\text { Asking patient/ } \\
\text { pregnant women } \\
\text { about oral healthcare } \\
\text { is outside routine } \\
\text { medical check-up/ } \\
\text { ANC practice }\end{array}$ & $\begin{array}{l}165 \\
(43.8)\end{array}$ & $\begin{array}{l}212 \\
(56.2)\end{array}$ & - \\
\hline $\begin{array}{l}\text { Cost of dental } \\
\text { treatment is barrier } \\
\text { to advising patients/ } \\
\text { pregnant women for } \\
\text { dental check-ups }\end{array}$ & $\begin{array}{l}199 \\
(52.8)\end{array}$ & $\begin{array}{l}178 \\
(47.2)\end{array}$ & - \\
\hline $\begin{array}{l}\text { There is need for } \\
\text { universal guidelines } \\
\text { for oral healthcare } \\
\text { during pregnancy } \\
\text { for all health } \\
\text { professionals }\end{array}$ & $\begin{array}{l}358 \\
(95.0)\end{array}$ & $19(5.0)$ & - \\
\hline
\end{tabular}

The participants are presented according to their ages (Table 2), working sectors (Figure 1), specialties (Figure 2) and highest academic qualifications (Table 3). The faculties from Basic Sciences and Community Medicine were grouped together as "Non-clinical" Specialty.

The total work experience after internship completion varied from a minimum of zero years to a maximum of 32 years (Mean \pm S.D. $=5.96 \pm 5.516$ years). Similarly when asked for work experience in antenatal care, it ranged from zero to 31 years (Mean \pm S.D. $=1.70 \pm$ 3.531).

\begin{tabular}{|lllll|}
\hline \multicolumn{4}{|l|}{ Table 2. Age categories of medical doctors. } \\
\hline $\begin{array}{l}\text { Age } \\
\text { Category } \\
\text { (years) }\end{array}$ & $\begin{array}{l}\text { Male } \\
\mathbf{n}(\%)\end{array}$ & $\begin{array}{l}\text { Female } \\
\mathbf{n}(\%)\end{array}$ & $\mathbf{n}(\%)$ & $\begin{array}{l}\text { Mean } \\
\pm \text { S.D. } \\
\text { (years) }\end{array}$ \\
$24-30$ & $121(32.1)$ & $\begin{array}{l}6 \\
(17.2)\end{array}$ & $\begin{array}{l}186 \\
(49.3)\end{array}$ & \\
& & $33(8.8)$ & 108 \\
$31-35$ & $75(19.9)$ & $38.6)$ & 31.94 \\
$36-45$ & $63(16.7)$ & $10(2.7)$ & $73(19.4)$ & \pm 5.76 \\
$46-60$ & $4(1.1)$ & $6(1.6)$ & $10(2.7)$ & \\
Total & $263(69.8)$ & 114 & 377 & \\
\hline
\end{tabular}

Minimum: 24 years; Maximum: 60 years. 


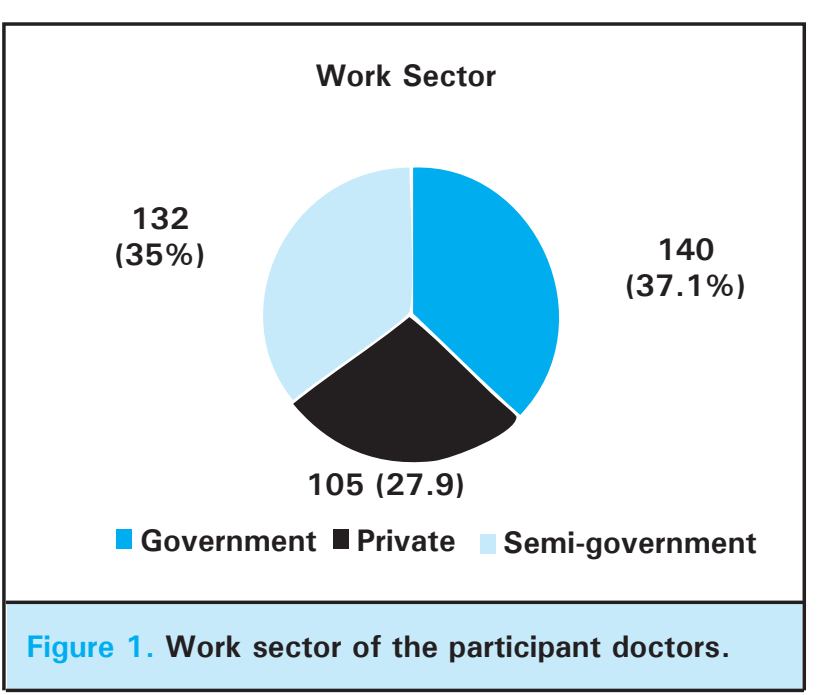

The number of pregnant women encountered per week varied a lot depending upon specialties and experience level. In an average it was found to be 22 pregnant women per week (mean $=22.43$ ).

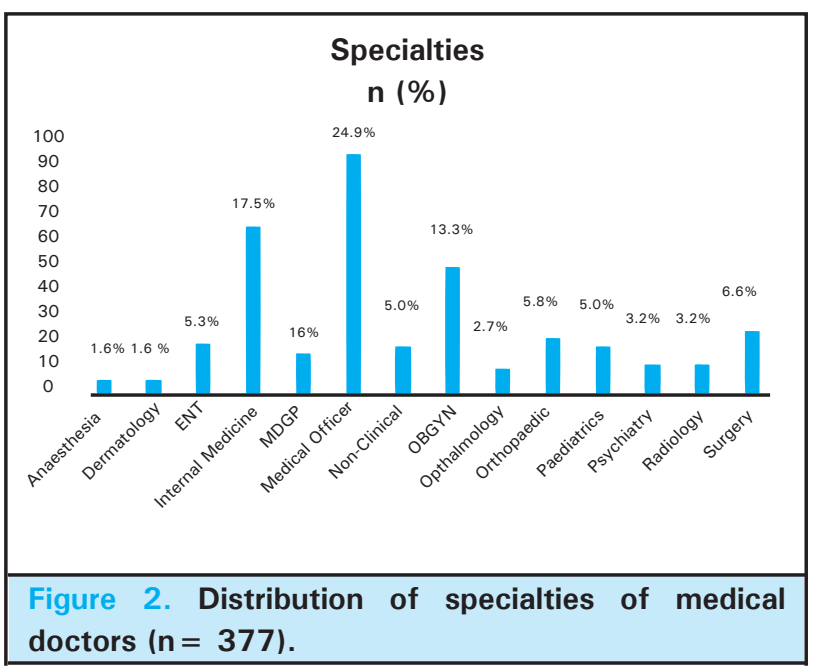

\begin{tabular}{|ll|}
\hline \multicolumn{2}{|l|}{ Table 3. Highest academic qualification. } \\
\hline Academic Qualification & $\mathbf{n}(\%)$ \\
Bachelors & $102(27.1)$ \\
Postgraduate Diploma & $30(8.0)$ \\
Masters/ Pursuing Masters & $187(49.6)$ \\
Fellowship & $26(6.9)$ \\
DM/ MCh & $19(5.0)$ \\
Doctorate (Phd.) & $4(1.1)$ \\
Postdoctorate (Post-Phd.) & $9(2.4)$ \\
Total & 377 \\
\hline
\end{tabular}

When asked, "How often do you encounter patients with oral/periodontal problem?" about 105 (27.9\%) confirmed as every week, 99 (26.3\%) on monthly basis, $75(19.9 \%)$ quarterly basis, 38 (10.1\%) yearly and $60(15.9 \%)$ answered as "never."
Only 108 (28.6\%) of the participating doctors "always" advised their patient for regular dental check-ups, while $244(64.7 \%)$ did "sometimes" and 25 (6.6\%) answered as "never."

\section{DISCUSSION}

Oral health, though an integral component of general health, is often overlooked by medical doctors. ${ }^{12-15}$ Periodontitis is frequent oral health problem globally. Periodontal health maintenance during pregnancy is an important aspect of ANC. Approximately $70 \%$ perinatal deaths occur due to PTD ( $<37$ weeks) or LBW $1<2500$ g). ${ }^{1}$ PTLBW affects the growth and overall health of the individuals throughout their lifetime. Hormonal variations during pregnancy put women at risk of suffering from various dental problems ${ }^{16}$ and poor maternal periodontal status has often been associated with adverse pregnancy outcomes. ${ }^{4,17}$ LBW and PTD are associated with increased local and systemic inflammatory mediators and intra-uterine infections. Evidence suggests that maternal periodontitis may represent potential source of microorganisms that routinely enter the circulation, and affect the health of foeto-maternal unit. ${ }^{18}$ The periodontal pathogens and by-products that reach placenta and spread to foetal circulation and amniotic fluid can elicit foetal immune/inflammatory response characterized by the production of antibodies and elevated inflammatory mediators levels that can induce miscarriage or PTD and LBW. ${ }^{19}$ Misconceptions surrounding oral healthcare during pregnancy by both healthcare providers and pregnant women may be contributing to the problem. ${ }^{11}$ Unfortunately, pregnant women and their ANC providers are unaware of the implications of poor oral health and seldom seek dental care during pregnancy. ${ }^{9}$ 10,20 There is increasing evidence to support this lack of awareness among medical doctors about periodontal health consequences and long-term risk associated with poor oral hygiene especially during pregnancy. $7,9,21,22$ Similarly, there is limited evidence about the perceptions of such ANC providers in Nepal towards provision of prenatal oral health care.

In the current study, medical doctors did not have adequate information on the impact of poor maternal oral health and rarely initiated this topic during prenatal care. Only $16.7 \%$ doctors knew that pyogenic granuloma and pregnancy tumour were same. Of them, 58.62\% doctors did not know that periodontitis was more serious than gingivitis. Among the doctors, $79.3 \%$ were aware of the possible connection between health of teeth and gums and pregnancy, $76.4 \%$ also agreed on pregnancy increasing gingival inflammation but only $59.4 \%$ agreed that tooth-gum problems could affect the pregnancy outcomes. This is in agreement with Al-Habashneh et al 
(2008), ${ }^{9}$ George et al (2012) ${ }^{11}$ and in contrast to Bhavya et al (2015). ${ }^{8}$ Despite acknowledging the importance of maternal oral health, very few medical doctors are wellinformed about prenatal oral health and supportive of dental treatments. Many doctors are uncertain about the safety of such procedures and are hesitant in referring pregnant women to dental specialists. ${ }^{11}$ This can be attributed to lack of education or training in oral care during pregnancy (only $13.8 \%$ had). Because of competing general health, ANC providers seldom focus on oral health care during antenatal care. ${ }^{11,23}$

Though $87.8 \%$ of doctors agreed that basic dental treatment is safe during pregnancy, only $28.6 \%$ of the doctors "always" advised their patient for regular dental checkups, while $64.7 \%$ did "sometimes" and 6.6\% answered as "never." This was similar to previous studies. $^{7-9,11}$ One of the reasons for non-referral to dentist could be the misconception that, no dental treatment should be performed during pregnancy. Although it is well-documented that dental treatments during pregnancy are safe, ${ }^{24,25}$ many doctors still believe that dental procedures could be risky and unsafe and often advise delaying dental treatment until after birth.

Dental radiography is another unclear area in ANC. About half, that is, $48.5 \%$ of the participants thought it was unsafe. Although it is universally acknowledged to be true for general radiography, the teratogenic risk of radiation exposure by dental radiography is 1,000 times less than the natural risk of spontaneous abortion or malformation. ${ }^{26}$ Yes, whenever possible, oral radiographs should be delayed until after first-trimester and screening radiography until after delivery, but it can be safely performed in pregnancy for acute diagnostic purposes ${ }^{16}$ with the help of lead aprons, thyroid shields, modern fast-films and avoiding retakes.

Many doctors $(43.8 \%)$ believed that asking patient or pregnant women about oral healthcare is outside routine medical checkup or ANC practice. Other studies have also reported similar findings. ${ }^{9,11}$ Few doctors $(35.3 \%)$ responded to lack of time to advise patients on oral health check-ups. Consequently, there is delay in dental care to pregnant women, resulting in postponing treatment beyond the safest period for treatment, the second trimester. ${ }^{24}$ About $58.1 \%$ doctors agreed that pregnancy exacerbated existing oral problems but half the doctors $(52.8 \%)$ thought cost to be barrier in advising patients for dental check-ups. Regular dental check-ups, preferably biannual visits can reduce cost of oral care to a negligent amount. Only when the treatment is delayed, dental treatments cost lot and number of visits to dentists increase.

Other important obstacles for dental care during pregnancy could be lack of adequate training on "oral healthcare during pregnancy" and fear of medicolegal consequences. Total of $95 \%$ doctors agreed that there is need for universal guidelines for oral healthcare during pregnancy. The American Academy of Periodontology recommends all women who are pregnant or planning to become pregnant, undergo periodontal examinations and necessary treatment. Internationally (UK, USA, Canada and Australia) have certain guidelines, though developing countries like Nepal lack such evidencebased guidelines for oral care of pregnant women.

The limitation is that the study was conducted among general doctors. Research among pure ANC providers like gynaecologists/obstetricians ${ }^{27}$ or general practitioners, internists ${ }^{28}$ and medical officers would have provided more accurate representation of actual scenario among Nepalese doctors. Similarly, the mechanism by which periodontitis has been associated with several poor pregnancy outcomes remains unclear and controversy exists. ${ }^{19,29}$ The benefits of periodontal treatment on pregnancy outcomes is not consistent. ${ }^{2,16,30}$ However, studies have reported no harm to mother or foetus from maternal periodontal treatment. ${ }^{18}$ In addition, a longer study period would have included larger population.

\section{CONCLUSIONS}

Medical doctors are in excellent position to promote maternal periodontal health and prevent associated adverse pregnancy outcomes. In context to Nepal, medical doctors are the ones who often deal with ANC. Their awareness can help decrease the chances of PTLBW due to oral and periodontal disease conditions. The findings of this study highlights the lack of knowledge and inadequate practices of doctors towards oral healthcare. It is recommended that all women should receive a comprehensive oral health evaluation during pregnancy and referred for appropriate dental treatment.

Another important issue is that treating periodontitis during pregnancy might be too late to achieve a positive result. Therefore, focus should be on improving the condition before pregnancy. In developed countries, it is strongly advised and promoted to visit their dentist by antenatal care providers. However, Nepal lacks such guidelines for the maintenance of oral health during pregnancy. Thus, there is need for training and reinforcement among doctors to take more active role in advising all patients for oral health maintenance, especially the women in fertile age groups. Lastly biannual dental check-ups to reduce cost and severity of oral conditions can go long way.

\section{ACKNOWLEDGEMENTS}


We acknowledge the help, support and motivation from Prof. Dr Shaili Pradhan, Dr Anjana Maharjan, Dr. Pooja Paudyal, Prof. Dr. Saroj Ojha, Dr. Neesha Shrestha, Dr Aashish Koirala and Ms Ashma Kafle. We are extremely thankful to all the participating doctors for their patience and generosity.

Conflict of interest: None.

\section{REFERENCES}

1. Santos-Pereira SA, Giraldo PC, Saba-Chujfi E, Amaral RL, Morais SS, Fachini AM, et al. Chronic periodontitis and pre-term labour in Brazilian pregnant women: an association to be analysed. J Clin Periodontol. 2007 Mar;34(3):208-13. [PubMed $\mid \underline{\text { Full Text } \mid \text { DOI] }}$

2. Mumghamba EG, Manji KP. Maternal oral health status and preterm low birth weight at Muhimbili National Hospital, Tanzania: a case-control study. BMC Oral Health. 2007 Jun 26;7:8. [PubMed | Full Text | DOI]

3. Corbella S, Taschieri S, Francetti L, De Siena F, Del Fabbro M. Periodontal disease as a risk factor for adverse pregnancy outcomes: a systematic review and meta-analysis of case-control studies. Odontology. 2012 Jul;100(2):232-40. [PubMed $\mid \underline{\text { Full Text } \mid \text { DOI] }}$

4. Lohana MH, Suragimath G, Patange RP, Varma S, Zope SA. A Prospective Cohort Study to Assess and Correlate the Maternal Periodontal Status with Their Pregnancy Outcome. J Obstet Gynaecol India. 2017 Feb;67(1):27-32. [PubMed | Full Text $\mid \underline{\text { DOI] }}$

5. Ide M, Papapanou PN. Epidemiology of association between maternal periodontal disease and adverse pregnancy outcomes--systematic review. J Clin Periodontol. 2013 Apr;40 Suppl 14:S181-94. [ubMed | Full Text | DOI]

6. Mehrotra V, Garg K, Sharma P, Sajid Z, Singh R. A Study Based on Dental Awareness, Knowledge and Attitudes among the Medical Practitioners in and Around Kanpur City (India). JBR J Interdiscipl Med Dent Sci. 2015;3(4). [Full Text]

7. George A, Dahlen HG, Reath J, Ajwani S, Bhole S, Korda A, et al. What do antenatal care providers understand and do about oral health care during pregnancy: a cross-sectional survey in New South Wales, Australia. BMC Pregnancy Childbirth. 2016 Dec 1;16(1):382-91. [PubMed | Full Text | DOI]

8. Bhavya B, Shaji V, Ashwini, S, Lavanya. Knowledge, practice and attitude of medical doctors on the association between medical health and periodontal health. J Dent Orofac Res. 2015 Jan-Jun;11(1):7-11. [Full Text]

9. Al-Habashneh R, Aljundi SH, Alwaeli HA. Survey of medical doctors' attitudes and knowledge of the association between oral health and pregnancy outcomes. Int J Dent Hygiene. 2008 Aug;6:214-20. [PubMed | Full Text | DOI]

10. Patil SN, Kalburgi NB, Koregol AC, Warad SB, Patil S, Ugale MS. Female sex hormones and periodontal health-awareness among gynecologists - A questionnaire survey. Saudi Dent J. 2012 Apr;24(2):99-104. [ubMed | Full Text | DOI]
11. George A, Shamim S, Johnson M, Dahlen H, Ajwani S, Bhole $S$, et al. How do dental and prenatal care practitioners perceive dental care during pregnancy? Current evidence and implications. Birth. 2012 Sep;39(3):238-47. [PubMed | Full Text | DOI]

12. Oyetola EO, Oyewole T, Adedigba M, Aregbesola ST, Umezudike K, Adewale A. Knowledge and awareness of medical doctors, medical students and nurses about dentistry in Nigeria. Pan Afr Med J. 2016 Apr 7;23:172-83. [PubMed | Full Text $\mid \underline{\text { DOI] }}$

13. Nagarakanti S, Epari V, Athuluru D. Knowledge, attitude, and practice of medical doctors towards periodontal disease. J Indian Soc Periodontol. 2013 Jan;17(1):137-9. [․ubMed | $\underline{\text { Full Text }} \mid \underline{\text { DOI] }}$

14. Alexia V, Chloe V, Pierre B, Sara LD. Periodontal Diseases and Systemic Disorders: What Do Our Doctors Know? A General Practitioner's Survey Conducted in Southern France. J Evid Based Dent Pract. 2017 Dec;17(4):361-9. [PubMed | Full Text | DOI]

15. Al-Habashneh R, Barghout N, Humbert L, Khader Y, Alwaeli H. Diabetes and oral health: doctors' knowledge, perception and practices. J Eval Clin Pract. 2010 Oct;16(5):976-80.

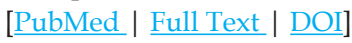

16. Silk HD, Douglass, AB, Douglass JM, Silk L. Oral health during pregnancy. Am Fam Physician. 2008 Apr 15;77(8):1139-44. [PubMed | Full Text]

17. Mawardi HH, Elbadawi LS, Sonis ST. Current understanding of the relationship between periodontal and systemic diseases. Saudi Med J. 2015 Feb;36(2):150-8. [PubMed | Full $\underline{\text { Text }}$ | DOI]

18. Sanz M, Kornman K, Working group 3 of joint EFP/AAP workshop. Periodontitis and adverse pregnancy outcomes: consensus report of the Joint EFP/AAP Workshop on Periodontitis and Systemic Diseases. J Clin Periodontol. 2013 Apr;40 Suppl 14:S164-9. [ㄹuMed | Full Text | DOI]

19. Madianos PN, Bobetsis YA, Offenbacher S. Adverse pregnancy outcomes (APOs) and periodontal disease: pathogenic mechanisms. J Clin Periodontol. 2013 Apr;40 Suppl 14:S170-80. [ubMed | Full Text | DOI]

20. Bamanikar S, Kee LK. Knowledge, attitude and practice of oral and dental healthcare in pregnant women. Oman Med J. 2013 Jul;28(4):288-91. [PubMed | Full Text | DOI]

21. Andhare MG, Dhonge RP, Dhuldhwaj RM, Dede RA, N. Sayyad IFN. A comparative evaluation of awareness regarding periodontal health and oral hygiene practices among dental and medical undergraduate students in Beed 
District of Maharashtra. Indian J Dent Sci. 2017;9(4):215-9. [Full Text | DOI]

22. Chitta H, Chaitanya NCSK, Lavanya R, Reddy MP, Imran, Subramanyam. Awareness of medical doctors on oral health: a cross sectional study. Oral Health Dent Manag. 2015;14(6):424-8. [Full Text]

23. Baseer MA, Alenazy MS, Alasqah M, Algabbani M, Mehkari A. Oral health knowledge, attitude and practices among health professionals in King Fahad Medical City, Riyadh. Dent Res J (Isfahan). 2012 Jul;9(4):386-92. [ㅁubMed | Full Text]

24. California Dental Association Foundation, American College of Obstetricians and Gynecologists, District IX. Oral health during pregnancy and early childhood: evidence-based guidelines for health professionals. J Calif Dent Assoc. 2010 Jun;38(6):391-403,405-40. [PubMed | Full Text]

25. Hughes D. Oral health during pregnancy and early childhood: barriers to care and how to address them. J Calif Dent Assoc. 2010 Sep;38(9):655-60. [ㅁubMed | Full Text]

26. Livingston HM, Dellinger TM, Holder R. Considerations in the management of the pregnant patient. Spec Care Dentist. 1998 Sep-Oct;18(5):183-8. [PubMed | Full Text | DOI]

27. Satyanarayana KV, Bai YD, Aruna P, Sindhura N, Monisha GR, Sreenivasulu G. Awareness on the association between periodontal diseases and pregnancy outcomes among gynecologists: a cross-sectional study. J Int Oral Health. 2016;8(5):579-84. [Full Text | DOI]

28. Umeizudike KA, Iwuala SO, Ozoh OB, Ayanbadejo PO, Fasanmade OA. Association between periodontal diseases and systemic illnesses: A survey among internal medicine residents in Nigeria. Saudi Dent J. 2016 Jan;28(1):24-30. [ $\underline{\text { PubMed }} \mid$ Full Text $\mid$ DOI]

29. Kunnen A, van Doormaal JJ, Abbas F, Aarnoudse JG, van Pampus MG, Faas MM. Periodontal disease and pre-eclampsia: a systematic review. J Clin Periodontol. 2010 Dec;37(12):1075-87. [PubMed | Full Text | DOI]

30. Michalowicz BS, Gustafsson A, Thumbigere-Math V, Buhlin $\mathrm{K}$. The effects of periodontal treatment on pregnancy outcomes. J Clin Periodontol. 2013;40 Suppl 14:S195-208. [PubMed | Full Text | DOI] 